\title{
内視鏡下経鼻的手術に必要な鼻腔の解剖
}

\author{
中川 隆之 ${ }^{1)}$ \\ 1）京都大学大学院医学研究科耳鼻咽喉科・頭頸部外科
}

\section{Surgical Anatomy of the Nasal Cavity for Endoscopic Transnasal Approach to the Skull Base}

\author{
Takayuki Nakagawa, M.D. ${ }^{1)}$ \\ 1) Department of Otolaryngology, Head and Neck Surgery, Graduate School of Medicine, Kyoto University
}

Recently, an endoscopic trans-nasal approach has become frequently used for skull base surgery. Depending on the extent of the skull base lesions, an appropriate corridor in the nasal cavity should be chosen to avoid excessive resection of important nasal constructions. For the mid-line approach including pituitary surgery, resection of the vomer and anterior wall of the sphenoid sinus provides sufficient surgical fields without resection of the middle turbinate. In some cases, partial resection of the superior turbinate is required. In cases in which surgical procedures around the carotid prominence and the optic nerve canal in the sphenoid sinus, ethmoidectomy via the middle meatus is necessary. In such cases, partial resection of the superior turbinate is required, but the middle turbinate can be preserved. It is also important to understand the anatomical relation between the sphenoid and posterior ethmoid sinus, especially to an Onodi cell, which if present would be located superiorly to the sphenoid sinus. For more advanced cases, maxillectomy is necessary to access to the lateral aspects of the sphenoid. The round canal and vidian canal are two important landmarks in this approach. When the pedicled mucoperiosteal septal flap is elevated for the reconstruction of the skull base, we should pay attention to the location of the olfactory epithelium and septal branches of the sphenopalatine artery.

(Received November 28, 2012; accepted December 14, 2012)

Key words : endoscopic transnasal surgery, middle turbinate, olfactory epithelium, Onodi cell, mucoperiosteal flap

Jpn J Neurosurg（Tokyo）22:357-361, 2013

\section{はじめに}

近年，脳神経外科領域でも下垂体を中心とした頭蓋底 領域に対する術式として，内視鏡下経鼻手術が一般化し つつある。内視鏡で得られる画像は，2D であり，画質 では顕微鏡に及ばないが，広い視野を獲得できる。さら に，近年の内視鏡画質の向上は著しく，手術用顕微鏡で 得られる画質との差は小さくなっている。内視鏡下手術 の利点として, 種々の斜視鏡の存在を挙げることができ
る、斜視鏡を使うことにより，顕微鏡下手術では視野に 入れることができない部位の観察が可能となる。内視鏡 下経鼻手術では，その視野の広さにより，眼窩，翼口蓋 窩，側頭下窩，嗅神経領域も明視下での手術操作が可能 となる。すざての手術アプローチは，鼻腔および副鼻腔 を経由するので, 鼻副鼻腔の構造物を適切に温存しつつ, 十分な術野を得る工夫が必要となる。本稿では，耳鼻咽 喉科医の立場から, 内視鏡下経鼻頭蓋底手術を行う際に, 脳神経外科医に知っておいていただきたい鼻副鼻腔解剖

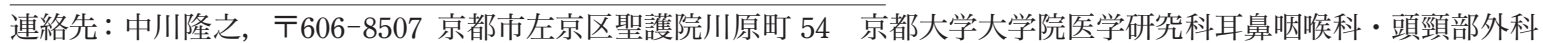

Address reprint requests to: Takayuki Nakagawa, M.D., Department of Otolaryngology, Head and Neck Surgery, Graduate School of Medicine, Kyoto University, 54 Kawahara-cho, Shogoin, Sakyo-ku, Kyoto 606-8507, Japan 


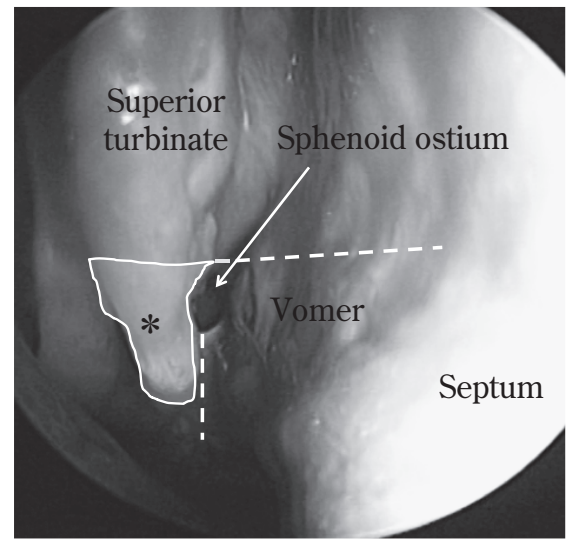

Fig. 1 Mucosal incision for the mid-line approach

An arrow indicates the sphenoid ostium in the right nasal cavity. Dotted lines demonstrate the design for the mucosal incision on the vomer and sphenoethmoidal recess. An asterisk indicates the resectable region of the superior turbinate.

を紹介する。

\section{下垂体など mid-line approach}

内視鏡下経鼻頭蓋底手術の第一段階の手術といえるの は，下垂体を中心とした，いわゆる mid-line approach と なる手術といえる。この術野は, 内視鏡下での手術操作 がうまくいかない場合に顕微鏡下手術に置き換えること が可能なことから，入門編とされる手術ではないかと思 う.このアプローチに際して問題となるのは, 中, 上鼻 甲介の取り扱いと嗅上皮温存にかかわる問題である。内 視鏡下手術であれば，顕微鏡下手術に比較して，簡便か つ低侵襲に術野に到達することができるので, 通常, 中, 上鼻甲介，嗅上皮のすべてを温存して手術を行うことが できる.アクセスが困難な症例でも, 上鼻甲介下半分切 除を追加すれば, 十分な術野が得られる. Fig. 1 に上鼻甲 介の下 $1 / 3$ を切除するアプローチにおける上鼻甲介の 切除範囲と蝶穊陥凹, 鼻中隔における粘膜切開線を示す。 両側鼻腔でこのアプローチを使えば，両側の内䅡動脈の 間の病変への良好なアプローチが可能となる ${ }^{3) 4}$. 蝶形骨 洞前壁と鋤骨を蝶形骨洞底の高さまでしつかり削ること が肝要であり, 手術操作に大きく影響する。蝶形骨洞自 然口よりも頭側に存在する嗅粘膜は温存される．実際の 症例を呈示する。症例は, 未端肥大症の下垂体腺腫例で, 右側で一部海綿静脈洞への浸潤が認められる（Fig. 2A,
B).この症例で, 上記のアプローチを行った術野の内視 鏡画像を Fig. $2 \mathrm{C}$ に呈示する。両側鼻腔からアプローチ することにより，腫瘍を全摘することができ，術後成長 ホルモン值は正常化した.

\section{内頚動脈隆起外側，視神経へのアプローチ}

次に術野をやや外側に拡大し, 内䅡動脈隆起外側, 視 神経管周辺での手術操作が必要な場合の鼻腔内のアプ ローチについて述べる．前述したアプローチに加え，中 鼻道から穊骨洞を蝶形骨洞まで開放すると，十分な操作 が可能となる.上鼻甲介下半分は切除することになるが, 中鼻甲介はすべて温存可能である。中鼻道での節骨洞開 放は, 日常耳鼻科医が行う副鼻腔手術の基本術式なので, 一般的な術式は成書を参照いただくこととし，特に注意 が必要な穊骨洞解剖について述べる。最後部節骨洞と蝶 形骨洞の位置関係は個人差が大きく，最後部節骨洞が大 きく蝶形骨洞の上に拡大している場合がある。このよう な篩骨洞を Onodi cell と呼ぶ (Fig. 3 $)^{6)}$ 。この場合, 視神 経管は蝶形骨洞ではなく, 後部節骨洞の外側壁に存在す る (Fig. 3)。したがって, 蝶形骨洞からは, 視神経管周 囲の操作はできない. 前述した mid-line approach に必要 な鼻腔内操作は，脳神経外科医のみで容易に操作できる が，ここで紹介するアプローチなど副鼻腔を介するアプ ローチでは，耳鼻咽喉科医と共同で手術を行うことのメ リットが大きくなるのではないかと考える.

\section{蝶形骨洞外側，側頭下窩へのアプローチ}

さらに, 術野を拡大し, 海綿静脈洞, 側頭下窩に操作 範囲が及ぶ場合について述べる。この場合，蝶形骨洞前 壁をすべて開放し，蝶形骨洞内すべてが操作可能としな ければならない。したがって, 蝶形骨洞の発育がよく, 外側に広く拡大している場合は，上顎洞後壁削除，翼口 蓋窩内容の下方への翻転が不可欠となる。このような術 野で重要な landmark となるのが, vidian 神経管と上䫈神 経管である。術前 CT でこれらの位置を把握し, 内䅡動 脈および海綿静脈洞との位置関係を把握しておく必要が ある.Vidian 神経は, まっすぐ後方にたどることにより内 頝動脈を同定することができる5)。この landmark が有用 であった症例を呈示する。この症例は, 蝶形骨に発生し た軟骨肉腫例で, 骨性の病変で内頝動脈を観察すること ができない（Fig. 4A，B）。このような場合，vidian 神経 および上顎神経を同定し，蝶形骨の外側と内頝動脈の位 置を予想することが必要となる。本症例では, vidian 神 

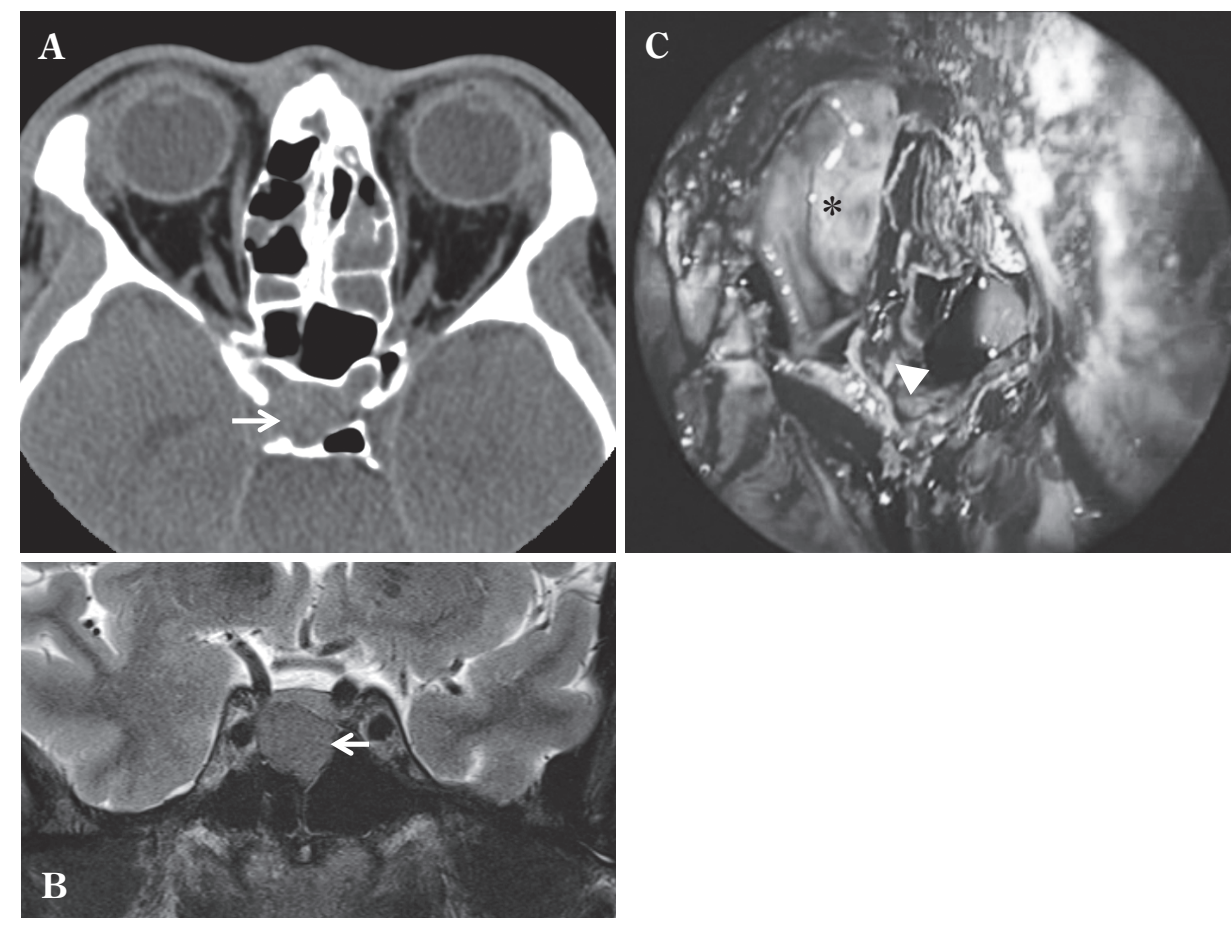

Fig. 2 CT image and endoscopic view of a growth hormone-secreting pituitary adenoma

A : An axial CT image of a growth hormone-secreting pituitary adenoma (arrow).

B : A coronal T2-MR image of the tumor (arrow).

C : An endoscopic view of the sphenoid sinus after resection of the vomer. An asterisk indicates the sella turcica, and an arrow head indicates the septum of the sphenoid sinus.
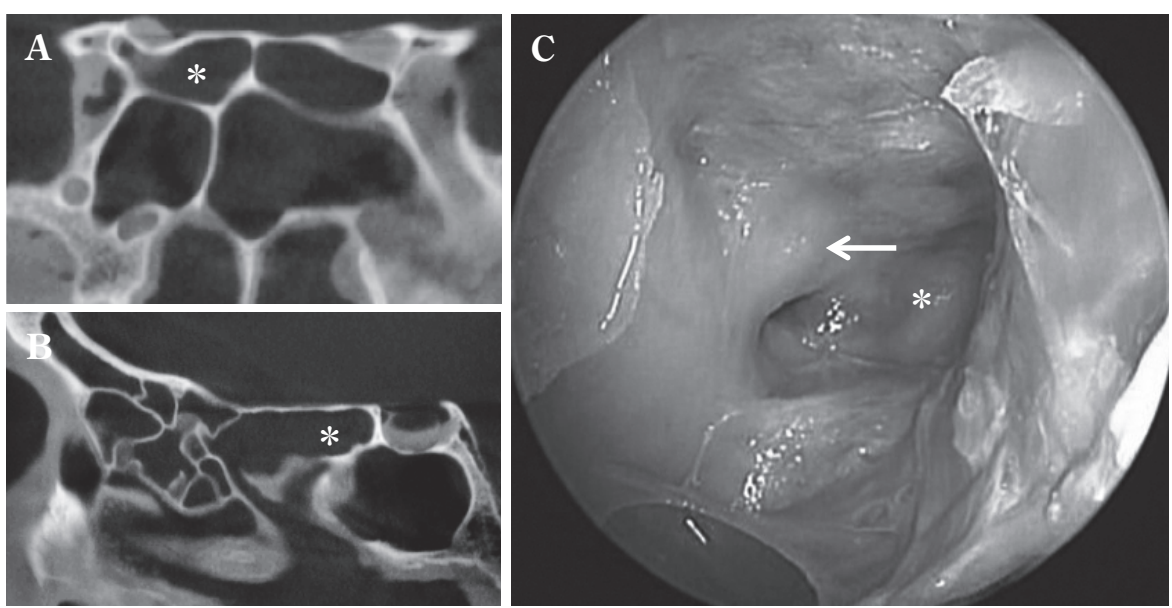

Fig. 3 CT images and endoscopic view of an Onodi cell

Coronal (A) and sagittal (B) CT images of an Onodi cell (asterisk). C : An endoscopic view of an Onodi cell (asterisk). The arrow indicates the optic nerve canal. 

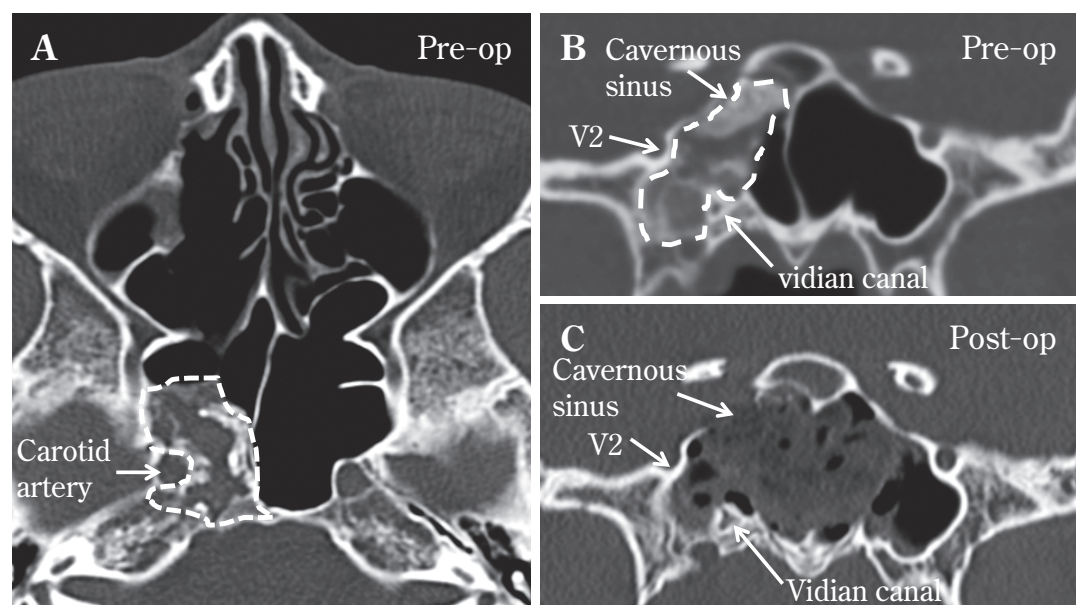

Fig. 4 Pre and postoperative CT images of chondrosarcoma of the sphenoid

Preoperative axial (A) and coronal (B) images of chondrosarcoma indicated by dotted lines. A postoperative coronal image (C).

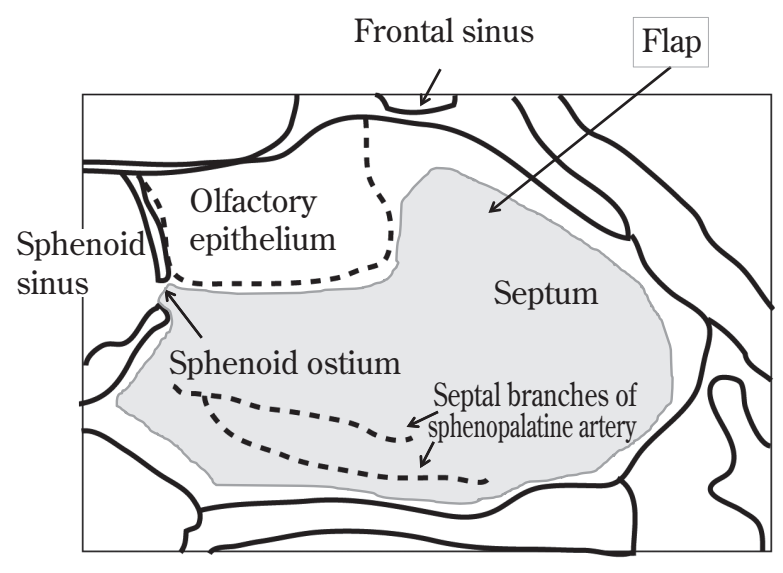

Fig. 5 Design of the pedicled mucoperiosteal septal flap

A schematic lateral image of the nasal septum of the right nasal cavity. The gray area indicates the design of the pedicled mucoperiosteal septal flap.

経および上顎神経を landmark とし, 骨性病変を削除する ことができた（Fig.4C）。

\section{有茎鼻中隔粘膜弁}

頭蓋底手術では, 病変の摘除に加えて, 頭蓋底再建も 重要な手術操作となる。有茥鼻中隔粘膜弁は, 頭蓋底再 建において重要な役割を果たしており, 有茎鼻中隔粘膜 弁の使用により，術後合併症が著しく減少することが報 告されている ${ }^{12)}$. 近年最も広く用いられている方法とも
いえる。ここでは，嗅上皮を適切に温存しつつ，前頭蓋 底再建に使用できる有茎鼻中隔粘膜弁の形成方法につい て述べる，鼻中隔の粘膜切開線のデザインで注意すべき ポイントは，嗅上皮を残存させることと蝶口蓋動脈鼻中 隔枝を粘膜弁に含めることである。嗅神経芽細胞腫の手 術の場合，嗅上皮は切除される側に含まれ，腫瘍断端の 迅速病理検査結果に応じて，粘膜弁として使用できる範 囲が規定される。通常，蝶穊陥凹から鉫骨にかけての粘 膜切開は，蝶形骨洞自然口の高さで行う。この鼻腔底に 水平な切開線をそのまま前方に伸長すると, 蝶口蓋動脈 鼻中隔枝を粘膜弁に含めることができ，嗅上皮を温存す ることができる。この切開線を中鼻甲介前端の位置まで 延長し，これより前方では，切開線の方向を上方に拡大 し, 必要に応じて粘膜弁を大きくすることができる (Fig. 5)。一般に，最前部の嗅糸は，嗅裂の前頭洞後壁のやや 後方で鼻腔内に入るため, 中鼻甲介前端より鼻孔側には 嗅上皮は存在しない。鼻孔部の皮膚粘膜移行部で切開線 を鼻腔底側に向け，鼻腔底では必要な粘膜弁の大きさに 応じて切開線の位置を決定する。後鼻孔まで後方に切開 線を延長し, 後鼻孔の上縁に沿って中鼻甲介の付着部ま で切開を伸ばす.粘膜弁を前方まで展開させたい場合は, 蝶口蓋孔まで粘膜弁の起始部を延長する。粘膜弁は，鼻 中隔から軟骨膜および骨膜を含める形で挙上する.

\section{おわりに}

内視鏡下経鼻頭蓋底手術に必要な鼻副鼻腔の解剖のポ イントについて, 実際の手術アプローチに応じて解説し 
た。本手術アプローチにおいて，脳神経外科医と耳鼻科 医の間でよく議論となる問題として, 鼻甲介温存の必要 性があるが，鼻甲介は鼻呼吸において重要な生理的な役 割を担うことに加え,手術に際しての重要な landmark と もなる，鼻甲介，鼻中隔粘膜の温存は，正常な鼻腔機能 の温存だけではなく, 再建材料, 再手術におけるアプロー チにおいても重要な役割を果たす。しかし，一方で安全 かつ有効性の高い手術を行うためには，適切な視野と術 野を獲得する必要性がある。標的となる病変の拡がりに 岕じて, 適切なアプローチを選択することが肝要であり, この点において脳神経外科医と耳鼻科医のさらなる協力

関係が構築されることを強く望んでやまない.

\section{文 献}

1) Hadad G, Bassagasteguy L, Carrau RL, Mataza JC, Kassam A, Snyderman CH, Mintz A: A novel reconstructive technique after endoscopic expanded endonasal approaches: vascular pedicle nasoseptal flap. Laryngoscope 116: 1882-1886, 2006.

2) Kassam AB, Prevedello DM, Carrau RL, Snyderman CH, Thomas A, Gardner P, Zanation, A, Duz B, Stefko ST, Byers K, Horowitz MB : Endoscopic endonasal skull base surgery: analysis of complications in the authors' initial 800 patients. J Neurosurg 114: 1544-1568, 2011.

3) Nakagawa T, Asada M, Takashima T, Tomiyama K: Sellar reconstruction after endoscopic transnasal hypophysectomy: use of mucosal flaps. Laryngoscope 111:20772081, 2001.

4）中川隆之，高島忠義，富山健太，朝田雅博：内視鏡によ る下垂体へのアプローチ法。日耳鼻１04：1-8，2001。

5) Osawa S, Rhoton AL Jr, Seker A, Shimizu S, Fujii K, Kassam AB: Microsurgical and endoscopic anatomy of the vidian canal. Neurosurgery 64 (Suppl 2) : 385-411, 2009.

6) Shin JH, Kim SW, Hong YK, Jeun SS, Kang SG, Kim SW, Cho JH, Park YJ: The Onodi cell: an obstacle to sellar lesions with a transsphenoidal approach. Otolaryngol Head Neck Surg 145: 1040-1042, 2011.

内視鏡下経鼻頭蓋底手術では，標的とする病変の拡がりに応じ，鼻副鼻腔の処理を行い，適切な術 野を確保する. Mid-line アプローチでは，中鼻甲介を温存しても，十分な術野を得ることができる. 内頝動脈隆起や視神経管周辺での手術操作が必要な場合，経中鼻道的にも蝶形骨洞の操作が行えるよ う, 篩骨洞開放が必要となる. 最後部篩骨洞のバリエーションである Onodi cell に注意が必要である. 蝶形骨洞外側にアプローチする場合, 上顎洞後壁削除が必要となる.Vidian 神経管と上顎神経管が有 用な目印になる．また，頭蓋底再建においては，嗅上皮と蝶口蓋動脈鼻中隔枝の位置を考慮した有茎 鼻中隔粘膜弁を作製する. 